BMJ Open Gastroenterology

\title{
Corticosteroid use and mortality risk in patients with perforated colonic diverticular disease: a population-based cohort study
}

\author{
L H A Broersen, ${ }^{1}$ E Horváth-Puhó, ${ }^{2}$ A M Pereira, ${ }^{1}$ R Erichsen, ${ }^{2} \mathrm{O}$ M Dekkers, ${ }^{1}$ \\ H T Sørensen ${ }^{2}$
}

To cite: Broersen LHA, Horváth-Puhó E, Pereira AM, et al. Corticosteroid use and mortality risk in patients with perforated colonic diverticular disease: a population-based cohort study. BMJ Open Gastro 2017;4:e000136. doi:10.1136/bmjgast-2017000136

- Additional material is available. To view please visit the journal (http://dx.doi.org/ 10.1136/bmjgast-2017000136)

Received 24 January 2017 Revised 1 March 2017 Accepted 3 March 2017

\section{${ }^{1}$ Division of Endocrinology, Department of Medicine, Leiden University Medical Centre, Leiden, \\ The Netherlands \\ ${ }^{2}$ Department of Clinical Epidemiology, Aarhus University Hospital, Aarhus, Denmark}

\section{Correspondence to} LHA Broersen;

I.h.a.broersen@lumc.nl

\section{ABSTRACT}

Background: Corticosteroids are a potential risk factor for mortality in patients with perforated diverticular disease, due to blinding of disease severity, hampered wound healing or adrenal insufficiency. We examined mortality in corticosteroid users and non-users among patients with perforated diverticular disease.

Methods: A cohort study based on medical databases including all patients $\geq 18$ years in Denmark (source population 5289261 inhabitants) admitted to a hospital with incident perforated diverticular disease between 2005 and 2013. 7-day, 1-month, 3-month and 1-year mortality risks in corticosteroid users and non-users were calculated using the Kaplan-Meier method, and compared with Cox proportional hazard regression adjusted for age, sex and comorbidities.

Results: The study included 4640 patients with perforated diverticular disease. Of these, $3743(80.7 \%)$ had not used corticosteroids in the year before admission and $725(15.6 \%)$ had been exposed to systemic corticosteroid treatment. The remaining 172 patients had been exposed to either inhaled or intestinal acting corticosteroid therapy. Mortality risk in non-users was $4.4 \%$ after 7 days and $15.6 \%$ after 1 year. This risk was doubled for corticosteroid users who filled their last prescription during the 90 days before admission, with mortality risks ranging from $14.2 \%$ after 7 days to $47.6 \%$ after 1 year. 1 -year mortality risk was even higher for corticosteroid users with a first filled prescription $\leq 90$ days before admission: $52.5 \%$.

Conclusions: Corticosteroid use was associated with clearly increased mortality risk after perforated diverticular disease. Thus, use of corticosteroids should be regarded as an important clinical prognostic factor for mortality in patients with this condition.

\section{INTRODUCTION}

In Western countries, the prevalence of colonic diverticular disease reaches $50 \%$ among persons aged 60 and older. ${ }^{1}{ }^{2}$ Although most patients remain asymptomatic, the lifetime risk for developing diverticulitis

\section{Summary box}

What is already known about this subject?

- Perforation is a well-known complication of diverticulitis.

- The incidence of perforated diverticular disease is $\sim 4$ per 100000 persons each year.

- Mortality risk after perforated diverticular disease requiring operative intervention has been reported to be $12-36 \%$ in small cohort studies.

- Use of corticosteroids is a potential risk factor affecting mortality in patients with perforated diverticular disease.

What are the new findings?

- Mortality risk was twice as high for current corticosteroids users compared with non-users.

- This is the first large cohort study comparing mortality risks between corticosteroid users and non-users among patients with perforated diverticular disease. We found that corticosteroid use is a strong indicator for 1-year mortality, with an absolute risk of about $50 \%$.

- Our study did not indicate a relation between corticosteroid dose and mortality risk.

How might it impact on clinical practice in the foreseeable future?

- Use of systemic corticosteroids should be regarded as an important risk marker for mortality in patients with perforated diverticular disease. Further multiangled evidence is needed to determine whether the association between corticosteroid use and mortality risk is causal.

is $\sim 10-25 \%,{ }^{3}$ which is known to present with perforation. ${ }^{4}$ The incidence of perforated diverticular disease is $\sim 4$ per 100000 persons each year, reported in hospital records in the UK of Great Britain and Northern Ireland and the USA. ${ }^{6}$ Mortality after perforated diverticular disease requiring operative intervention has been reported to be as high as 
$12-36 \%$ in small cohort studies $\left(78-121\right.$ cases).${ }^{78}$ Given this high mortality risk, a better understanding of prognostic factors associated with mortality is clearly needed.

Use of corticosteroids is a potential prognostic factor affecting mortality in patients with perforated diverticular disease. Corticosteroids are widely prescribed for inflammatory diseases, malignancies and after organ transplantation, in order to inhibit an inflammatory response. ${ }^{9-11}$ At the same time, corticosteroids have been associated with bowel perforation in patients with diverticular disease. Three case-control studies reported increased ORs of 1.7 to 28.3 and one cohort study reported a relative risk of 2.2. ${ }^{12-15}$ A recent meta-analysis showed ORs for perforation of diverticular disease after use of corticosteroids of 2.17 to $31.90 .^{16}$

There are several reasons why mortality may be increased in patients with perforated diverticular disease who use corticosteroids. Disease severity might be masked by use of corticosteroids, ${ }^{17}$ leading to incorrect staging of disease severity and, consequently, inadequate treatment. ${ }^{6}$ Corticosteroid use might hamper wound healing as well through its anti-inflammatory effects, by suppressing cellular wound responses and by inducing diabetes, and thus increasing the risk of wound infection. ${ }^{18}$ A systematic review also showed that corticosteroid use may increase the risk of anastomotic leakage after colorectal surgery. ${ }^{19}$ Use of corticosteroids is associated with an increased risk of venous thromboembolism. ${ }^{20}$ In perforated diverticulitis, undiagnosed and untreated adrenal insufficiency may lead to an Addisonian crisis, which increases mortality risk in affected patients. $^{21}$

\section{Study aims}

The primary aim of this study was to examine absolute mortality risks and compare 7-day, 1-month, 3-month and 1-year mortality rates in patients with perforated diverticular disease who were corticosteroid users versus non-users. The secondary aim was to examine mortality rates in patients with perforated diverticular disease who used corticosteroids administered in different forms and with different cumulative doses.

\section{METHODS}

Source population

The source population for this study was the entire population of Denmark (5 289261 inhabitants) between 2005 and 2013. The study period began in 2005 because a full record of medications sold at community pharmacies and hospital-based outpatient pharmacies became available starting in 2004 in the National Health Service Prescription Database. ${ }^{22}$ The study was based on data from the Danish National Patient Registry, which has recorded all acute care hospital discharges since 1977 and all outpatient specialist clinic and emergency room visits since 1995. ${ }^{23}$ Data from the Danish Civil Registration System were used to determine vital status. ${ }^{24}$
Study population and follow-up

The study included all adult patients ( $\geq 18$ years), with and without use of corticosteroids, hospitalised with incident perforated diverticular disease between 2005 and 2013. Identification of perforated and non-perforated diverticular disease was based on International Classification of Diseases (ICD) codes (see online supplementary appendix 1 for specification of the codes). The codes used for perforated diverticular disease have a positive predictive value ranging from 0.73 to $0.75 .^{25}$ There were no restrictions in corticosteroid dose or treatment duration. Patients diagnosed during an emergency room visit were excluded because of the low predictive value of emergency room diagnoses; diagnostic accuracy improves with more extensive diagnostic procedures. ${ }^{26}$ The year 2005 as start of follow-up was chosen in order to provide a 1-year prediagnosis period in which exposure to corticosteroids could be assessed similarly in all patients. Patient follow-up began on the hospital admission date for perforated diverticular disease and ended on death, emigration or end of follow-up on 30 November 2013, whichever came first.

\section{Classification of corticosteroid use and surgical procedures}

Corticosteroid use was categorised as follows, based on the National Health Service Prescription Database. ${ }^{22}$

I. Non-users: patients not prescribed corticosteroids during the year prior to hospital admission.

II. Current users: patients using corticosteroids at time of admission, that is, the last prescription for corticosteroids was filled during the 90 days before admission. The group of current users was subdivided into new users, defined as patients who filled their first prescription $\leq 90$ days before admission, and chronic users, which included all other current users.

III. Recent users: patients who used corticosteroids until shortly before admission, that is, their last corticosteroid prescription was filled between 91 and 365 days before admission.

Analyses were performed separately for patients using systemic corticosteroids regardless of use of other forms of corticosteroids, for patients using systemic corticosteroids only, for patients using inhaled corticosteroids only, and for patients using intestinal acting corticosteroids only. There was one patient using both inhaled and intestinal acting corticosteroids.

The analysis of cumulative dose was based on categorising the 1-year cumulative dose of systemic corticosteroids among current users, calculated using prednisone dose equivalents. The cumulative dose cut-offs were $\leq 625,>625$ to $2000,>2000$ to 3500 and $>3500 \mathrm{mg}$, to provide four groups of approximately equal size.

Surgical procedures related to diverticular perforation (including a 30-day period around date of admission for diverticular disease) were categorised as explorative surgery including lavage; stoma with or without resection; and resections with primary 
anastomosis (see online supplementary appendix 2 for surgical codes).

\section{Statistical analysis}

Descriptive contingency tables were prepared, showing demographic characteristics and medical history (age, sex, calendar year of perforated diverticular disease diagnosis, comorbidities) of corticosteroid users and non-users.

For time-to-event analyses, the Kaplan-Meier method and Cox regression were used. Absolute mortality risks in corticosteroid users and non-users were calculated using the Kaplan-Meier method. Cox proportional hazard regression was used to compare mortality rates among the predefined categories of corticosteroid users, providing HRs for 7-day, 1-month, 3-month and 1-year mortality. Stratified analyses were performed according to type of surgery within 30 days before or after diagnosis of perforated diverticular disease.

Subgroup analyses were performed to compare mortality risks among patients taking different forms of corticosteroids (inhaled only, intestinal only and systemic only) and with different 1-year cumulative doses of systemic corticosteroid use. Also, sensitivity analyses were performed after excluding patients with malignancies, patients with inflammatory bowel disease, patients with a previous code for diverticular disease and patients with rheumatic diseases including mixed connective tissue disease.

In addition to crude analyses, we performed adjusted analyses including the following potential confounders: age, sex, use of cardiovascular medications (anticoagulants, non-steroidal anti-inflammatory drugs, ACE/angiotensin 2 receptor (A2R) inhibitors, statins, $\beta$ blockers, calcium channel blockers, diuretics, selective serotonin reuptake inhibitors (SSRIs) and nitrates) ${ }^{16}$ during the 90 days before admission, hypertension, chronic obstructive pulmonary disease (COPD; as a proxy for smoking), liver disease or chronic pancreatitis, alcoholism-related diseases other than those affecting the liver or pancreas, inflammatory bowel disease, rheumatoid arthritis, connective tissue disease, malignancies and modified Charlson Comorbidity Index score (see online supplementary appendix 1 for specification of the codes). The modified Charlson Comorbidity Index score was calculated after exclusion of COPD, liver diseases, connective tissue disease and malignancies. These characteristics and conditions are associated with corticosteroid use and constitute potential risk factors for mortality.

We used SAS V.9.2 (SAS Institute, Cary, North Carolina, USA) for our statistical analyses. Permission from the Danish Data Protection Board was granted.

\section{RESULTS}

\section{Study population}

A total of 4640 patients with perforated diverticular disease were included in the study. Of these, 3743 $(80.7 \%)$ had not used corticosteroids in the year before hospital admission (table 1). Of the 897 patients using corticosteroids in the prior year, 725 (80.8\%) were exposed to systemic corticosteroid treatment (current and recent users combined). Of systemic corticosteroid users, $88.8 \%$ used prednisone or prednisolone, $6.9 \%$ methylprednisolone, $13.4 \% \quad \beta$-methasone, $1.5 \%$ triamcinolone and $1.0 \%$ hydrocortisone. Since the number of patients using only intestinal acting corticosteroids was small $(n=28)$, this patient group was not analysed further. Corticosteroid users were on average older than non-users and more often female than non-users $(64.8 \%$ vs $54.2 \%)$. Patients using systemic corticosteroids were more often hypertensive, more often had COPD, chronic bronchitis, emphysema or asthma, and more often had malignancies, rheumatoid arthritis, connective tissue disease or inflammatory bowel disease. Almost all patients using only inhaled corticosteroids had a diagnosis of COPD, chronic bronchitis, emphysema or asthma, but were otherwise comparable to non-users. Charlson Comorbidity Index scores were higher for all groups of corticosteroid users compared with non-users.

\section{Mortality risk in patients with perforated colonic diverticular disease}

A total of 889 patients (19.2\%) with perforated diverticulitis died within 1 year following their diagnosis (table 2). Mortality risk in non-users of corticosteroids was $4.4 \%$ after 7 days, $8.8 \%$ after 30 days, $11.9 \%$ after 90 days and $15.6 \%$ after 1 year. This risk was doubled for current users of corticosteroids (adjusted HRs ranging from 1.96 (30-day mortality) to 2.10 (7-day mortality)), with mortality risks reaching $14.2 \%$ after 7 days and $47.6 \%$ after 1 year (figure 1). Mortality risk was even higher for new corticosteroid users, increasing from $15.7 \% 7$ days postdiagnosis to $52.5 \%$ after 1 year. Among chronic corticosteroid users, mortality risks also were almost doubled, with adjusted HRs of 1.89 after 7 days and 1.74 after 1 year, and absolute mortality risks reaching $13.7 \%$ after 7 days and $45.9 \%$ after 1 year.

\section{Mortality risk according to 1-year cumulative dose}

In our study population, 124 patients had a 1-year cumulative dose $\leq 625 \mathrm{mg}, 144$ patients had a 1-year cumulative dose $>625-2000 \mathrm{mg}, 140$ patients had a 1-year cumulative dose $>2000-3500 \mathrm{mg}$ and 86 patients had a 1-year cumulative dose $>3500 \mathrm{mg}$ (table 3). A higher 1-year cumulative dose was not clearly associated with higher mortality risk in patients with perforated diverticular disease.

\section{Abdominal surgical procedures}

In total, 2497 (53.8\%) of 4640 patients had a diverticulitis-related surgical procedure (table 1). The percentage of patients with surgery within 30 days before or after incident perforated diverticular disease was higher among systemic corticosteroid users (62.9\%) compared with users of inhalation corticosteroids only $(56.6 \%)$ and non-users $(52.1 \%)$. Patients using systemic corticosteroids had a surgical procedure resulting in a 
Table 1 Baseline characteristics of corticosteroid users and non-users among patients with perforated diverticular disease

\begin{tabular}{|c|c|c|c|c|c|c|c|c|}
\hline & \multicolumn{2}{|c|}{ Non-use } & \multicolumn{2}{|c|}{$\begin{array}{l}\text { Systemic use } \\
\text { regardless of } \\
\text { other uses }\end{array}$} & \multicolumn{2}{|c|}{$\begin{array}{l}\text { Systemic use } \\
\text { only }\end{array}$} & \multicolumn{2}{|c|}{$\begin{array}{l}\text { Inhaled use } \\
\text { only }\end{array}$} \\
\hline & $\mathbf{N}$ & Per cent & $\mathbf{N}$ & Per cent & $\mathbf{N}$ & Per cent & $\mathbf{N}$ & Per cent \\
\hline Total & 3743 & 100.0 & 725 & 100.0 & 656 & 100.0 & 145 & 100.0 \\
\hline Current use & - & - & 494 & 68.1 & 446 & 68.0 & 81 & 55.9 \\
\hline New use & - & - & 121 & 16.7 & 109 & 16.6 & 7 & 4.8 \\
\hline Chronic use & - & - & 373 & 51.4 & 337 & 51.4 & 74 & 51.1 \\
\hline Recent use & - & - & 231 & 31.9 & 210 & 32.0 & 64 & 44.1 \\
\hline \multicolumn{9}{|l|}{ Age, years } \\
\hline $18-59$ & 1431 & 38.2 & 119 & 16.4 & 113 & 17.2 & 42 & 29.0 \\
\hline $60-69$ & 860 & 23.0 & 146 & 20.1 & 133 & 20.3 & 37 & 25.5 \\
\hline $70-79$ & 777 & 20.8 & 239 & 33.0 & 213 & 32.5 & 41 & 28.3 \\
\hline $80+$ & 675 & 18.0 & 221 & 30.5 & 197 & 30.0 & 25 & 17.2 \\
\hline Gender (male) & 1713 & 45.8 & 256 & 35.3 & 232 & 35.4 & 56 & 38.6 \\
\hline \multicolumn{9}{|c|}{ Calendar year of perforated diverticular disease diagnosis } \\
\hline 2005-2008 & 1556 & 41.6 & 328 & 45.2 & 294 & 44.8 & 60 & 41.4 \\
\hline 2009-2013 & 2187 & 58.4 & 397 & 54.8 & 362 & 55.2 & 85 & 58.6 \\
\hline \multicolumn{9}{|l|}{ Comorbidities } \\
\hline $\begin{array}{l}\text { Diverticular disease of the colon without } \\
\text { perforation }\end{array}$ & 897 & 24.0 & 173 & 23.9 & 151 & 23.0 & 36 & 24.8 \\
\hline Hypertension & 844 & 22.5 & 263 & 36.3 & 247 & 37.7 & 39 & 26.9 \\
\hline $\begin{array}{l}\text { COPD, chronic bronchitis, emphysema } \\
\text { and asthma }\end{array}$ & 682 & 18.2 & 334 & 46.1 & 278 & 42.4 & 137 & 94.5 \\
\hline Liver disease and/or chronic pancreatitis & 111 & 3.0 & 25 & 3.4 & 24 & 3.7 & 5 & 3.4 \\
\hline $\begin{array}{l}\text { Alcoholism-related diseases other than } \\
\text { those affecting the liver or pancreas }\end{array}$ & 310 & 8.3 & 42 & 5.8 & 38 & 5.8 & 13 & 9.0 \\
\hline Cancer & 503 & 13.4 & 201 & 27.7 & 189 & 28.8 & 19 & 13.1 \\
\hline $\begin{array}{l}\text { Rheumatoid arthritis/connective tissue } \\
\text { disease }\end{array}$ & 138 & 3.7 & 200 & 27.6 & 186 & 28.4 & 4 & 2.8 \\
\hline Inflammatory bowel disease & 71 & 1.9 & 40 & 5.5 & 32 & 4.9 & 4 & 2.8 \\
\hline \multicolumn{9}{|l|}{ Charlson Comorbidity Index score } \\
\hline 0 & 2659 & 71.0 & 371 & 51.2 & 334 & 50.9 & 99 & 68.3 \\
\hline $1-2$ & 888 & 23.7 & 261 & 36.0 & 241 & 36.7 & 36 & 24.8 \\
\hline$\geq 3$ & 196 & 5.2 & 93 & 12.8 & 81 & 12.3 & 10 & 6.9 \\
\hline $\begin{array}{l}\text { Surgery within } 30 \text { days before or after } \\
\text { diagnosis of diverticulitis (total) }\end{array}$ & 1949 & 52.1 & 456 & 62.9 & 425 & 64.8 & 82 & 56.6 \\
\hline Explorative surgery including lavage & 616 & 16.5 & 115 & 15.9 & 108 & 16.5 & 24 & 16.6 \\
\hline Stoma & 845 & 22.6 & 245 & 33.8 & 228 & 34.8 & 38 & 26.2 \\
\hline Resection with primary anastomosis & 488 & 13.0 & 96 & 13.2 & 89 & 13.6 & 20 & 13.8 \\
\hline
\end{tabular}

stoma $(33.8 \%)$ more often than patients not using corticosteroids $(22.6 \%)$.

Within categories of surgery (explorative surgery including lavage, stoma, resection with primary anastomosis), mortality risk was increased when comparing current users to non-users. After explorative surgery, mortality risk after 1 year was $14.8 \%$ for non-users and $43.5 \%$ for current users (adjusted HR 1.12 (95\% CI 0.69 to 1.83$)$ ). For patients who received a stoma, mortality risk after 1 year was $26.5 \%$ for non-users and $48.8 \%$ for current users (adjusted HR 1.37 (95\% CI 1.03 to 1.82)). After a resection with primary anastomosis, mortality risk after 1 year was $15.2 \%$ for non-users and $54.1 \%$ for current users (adjusted HR 2.88 (95\% CI 1.57 to 5.28)).
Subgroup and sensitivity analyses

The mortality risk among patients currently using systemic corticosteroids only (13.9\% after 7 days and $48.0 \%$ after 1 year) was comparable to that among patients using systemic corticosteroids regardless of other corticosteroid use (figure 2). Compared with non-users, patients who currently used only inhaled corticosteroids also had an increased mortality risk $(6.2 \%$ after 7 days and $22.3 \%$ after 1 year), with an adjusted HR ranging from 1.44 to 1.85 (table 4).

When we excluded patients with malignancies, inflammatory bowel disease, a previous code for diverticular disease, or rheumatic diseases including mixed connective tissue disease, the results of the analysis of current users of systemic corticosteroids regardless of use of 
Table 2 Mortality among patients with systemic corticosteroid use, regardless of use of intestinal acting or inhaled corticosteroids compared with non-use

\begin{tabular}{|c|c|c|c|c|c|}
\hline Corticosteroid use & Period & $\begin{array}{l}\text { Absolute risk } \\
(95 \% \mathrm{CI})\end{array}$ & $\begin{array}{l}\text { Rate per } 1000 \text { PYRs } \\
(95 \% \mathrm{Cl})\end{array}$ & $\begin{array}{l}\text { Crude HR } \\
(95 \% \mathrm{Cl})\end{array}$ & $\begin{array}{l}\text { Adjusted HR* } \\
(95 \% \mathrm{Cl})\end{array}$ \\
\hline \multirow[t]{4}{*}{ Non-use } & 7 days & 4.4 (3.8 to 5.1$)$ & 6.46 (5.47 to 7.44$)$ & & \\
\hline & 30 days & 8.8 (7.9 to 9.7$)$ & 3.12 (2.78 to 3.45$)$ & & \\
\hline & 90 days & 11.9 (10.9 to 12.9$)$ & 1.46 (1.33 to 1.60$)$ & & \\
\hline & 1 year & 15.6 (14.4 to 16.8$)$ & 0.51 (0.47 to 0.55$)$ & & \\
\hline \multirow[t]{4}{*}{ Current use } & 7 days & 14.2 (11.4 to 17.6$)$ & 21.81 (16.70 to 26.92$)$ & 3.38 (2.56 to 4.47$)$ & 2.10 (1.52 to 2.90$)$ \\
\hline & 30 days & 27.9 (24.2 to 32.1$)$ & $11.53(9.60$ to 13.45$)$ & 3.56 (2.92 to 4.35$)$ & 1.96 (1.56 to 2.47 ) \\
\hline & 90 days & 36.6 (32.5 to 41.0$)$ & 5.71 (4.87 to 6.54$)$ & 3.59 (3.02 to 4.27$)$ & 1.97 (1.62 to 2.41$)$ \\
\hline & 1 year & 47.6 (43.2 to 52.1$)$ & 2.22 (1.93 to 2.50$)$ & 3.75 (3.22 to 4.38$)$ & 2.05 (1.72 to 2.45$)$ \\
\hline \multirow[t]{4}{*}{ New use } & 7 days & 15.7 (10.3 to 23.5$)$ & 24.20 (13.32 to 35.09$)$ & 3.75 (2.33 to 6.03$)$ & 2.88 (1.77 to 4.70$)$ \\
\hline & 30 days & 31.4 (23.9 to 40.5$)$ & $13.46(9.18$ to 17.73$)$ & 4.09 (2.92 to 5.73$)$ & 2.72 (1.92 to 3.85$)$ \\
\hline & 90 days & 46.3 (37.9 to 55.6$)$ & 7.87 (5.81 to 9.93$)$ & 4.75 (3.60 to 6.28$)$ & 3.06 (2.29 to 4.09$)$ \\
\hline & 1 year & 52.5 (43.9 to 61.7$)$ & 2.83 (2.13 to 3.53$)$ & 4.43 (3.41 to 5.75$)$ & 2.89 (2.21 to 3.79$)$ \\
\hline \multirow[t]{4}{*}{ Chronic use } & 7 days & 13.7 (10.6 to 17.6$)$ & 21.04 (15.27 to 26.81$)$ & 3.26 (2.38 to 4.46$)$ & 1.89 (1.30 to 2.74$)$ \\
\hline & 30 days & 26.8 (22.6 to 31.6$)$ & 10.93 (8.79 to 13.07$)$ & 3.40 (2.71 to 4.25$)$ & 1.68 (1.29 to 2.19$)$ \\
\hline & 90 days & 33.4 (28.8 to 38.4$)$ & 5.08 (4.18 to 5.97$)$ & 3.23 (2.65 to 3.94$)$ & 1.58 (1.25 to 2.00$)$ \\
\hline & 1 year & 45.9 (40.9 to 51.2$)$ & 2.05 (1.74 to 2.36$)$ & 3.54 (2.98 to 4.21$)$ & 1.74 (1.42 to 2.14$)$ \\
\hline \multirow[t]{4}{*}{ Recent use } & 7 days & 6.1 (3.6 to 10.0) & 8.97 (4.27 to 13.67$)$ & $1.39(0.81$ to 2.40$)$ & $1.11(0.63$ to 1.95$)$ \\
\hline & 30 days & 13.9 (10.0 to 19.1$)$ & 5.12 (3.34 to 6.89$)$ & 1.63 (1.13 to 2.34$)$ & 1.15 (0.79 to 1.68$)$ \\
\hline & 90 days & 19.2 (14.7 to 24.9$)$ & 2.53 (1.78 to 3.28$)$ & 1.68 (1.24 to 2.30$)$ & 1.17 (0.84 to 1.61$)$ \\
\hline & 1 year & 26.3 (21.0 to 32.6 ) & 0.95 (0.71 to 1.20$)$ & 1.78 (1.36 to 2.33$)$ & 1.23 (0.93 to 1.63$)$ \\
\hline
\end{tabular}

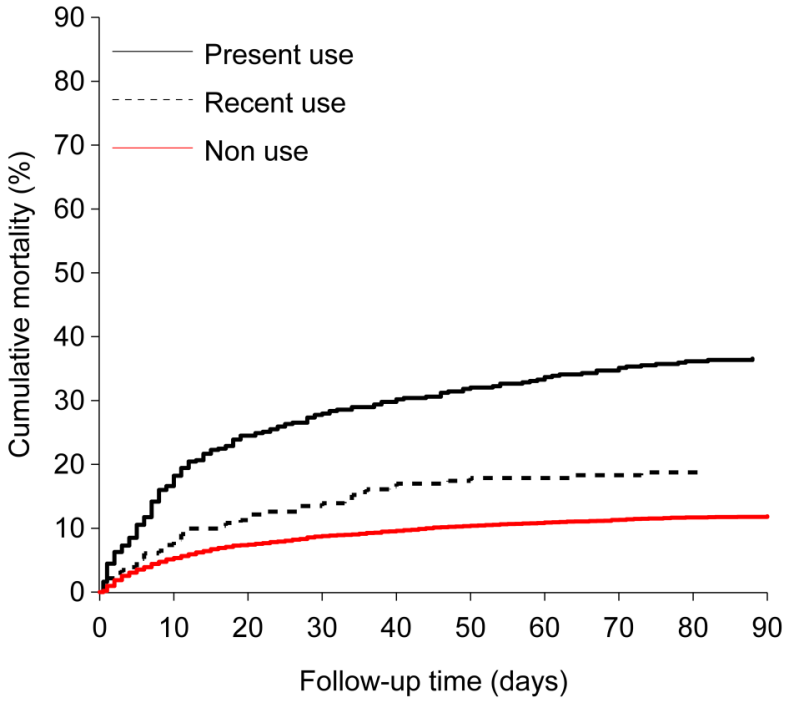

Number at risk:

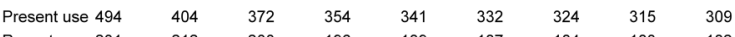
Recent use 231

Figure 1 Cumulative mortality in patients with systemic corticosteroid use, regardless of other use.

other corticosteroids did not materially change for mortality risk after 7, 30, 90 days or 1 year.

\section{DISCUSSION}

We examined mortality risks between corticosteroid users and non-users among patients with perforated diverticular disease. One-year mortality risk for current users of corticosteroids was $47.6 \%$, double that of non-users after adjustment for confounders. One-year mortality risk was even higher for new corticosteroid users: $52.5 \%$. Thus, corticosteroid use was clearly associated with an increased mortality risk for patients with perforated diverticular disease, continuing until at least 1 year after diagnosis, regardless of corticosteroid dose.

This is the first large cohort study comparing mortality risks between corticosteroid users and non-users among patients with perforated diverticular disease. The advantage of the cohort approach is the ability to calculate absolute mortality risks, which can inform clinical practice. Our study showed that corticosteroid use is a strong indicator for 1-year mortality. An earlier study of patients with perforated peptic ulcer disease reported a 30-day mortality ratio of 2.1 after corticosteroid use. ${ }^{27}$ This is in line with the increased mortality risk (adjusted HR of 1.96 for 30-day mortality) that we found among current users of systemic corticosteroids in the present study.

The following study limitations need to be taken into account in interpreting our results. Determination of exposure was based on redeemed prescriptions, which may not always coincide completely with medication taken by patients. ${ }^{28}$ We also did not consider use of corticosteroids for longer than a year before hospital admission. Also, since prednisolone and prednisone were the most frequently used systemic steroids $(89 \%)$, the results in first line apply to this patient category; whether our 
Table 3 Mortality among patients with current use of systemic corticosteroids, regardless of other corticosteroid use, according to 1-year cumulative dose compared with non-use

\begin{tabular}{|c|c|c|c|c|c|}
\hline $\begin{array}{l}\text { Cumulative dose of } \\
\text { corticosteroids }^{*}\end{array}$ & Period & $\begin{array}{l}\text { Absolute risk } \\
(95 \% \mathrm{Cl})\end{array}$ & $\begin{array}{l}\text { Rate per } 1000 \text { PYRs } \\
(95 \% \mathrm{Cl})\end{array}$ & $\begin{array}{l}\text { Crude HR } \\
(95 \% \mathrm{Cl})\end{array}$ & $\begin{array}{l}\text { Adjusted HR† } \\
(95 \% \mathrm{Cl})\end{array}$ \\
\hline \multirow[t]{4}{*}{ Non-use } & 7 days & 4.4 (3.8 to 5.1$)$ & $6.46(5.47$ to 7.44$)$ & & \\
\hline & 30 days & 8.8 (7.9 to 9.7$)$ & 3.12 (2.78 to 3.45$)$ & & \\
\hline & 90 days & 11.9 (10.9 to 12.9$)$ & $1.46(1.33$ to 1.60$)$ & & \\
\hline & 1 year & $15.6(14.4$ to 16.8$)$ & $0.51(0.47$ to 0.55$)$ & & \\
\hline \multirow[t]{4}{*}{$\leq 625 \mathrm{mg}$} & 7 days & 15.3 (10.1 to 23.0$)$ & $23.54(12.96$ to 34.13$)$ & 3.65 (2.27 to 5.87 ) & 2.38 (1.44 to 3.92$)$ \\
\hline & 30 days & 26.6 (19.7 to 35.3$)$ & 10.95 (7.22 to 14.69$)$ & 3.38 (2.37 to 4.84$)$ & 1.92 (1.32 to 2.79$)$ \\
\hline & 90 days & 37.9 (30.0 to 47.1$)$ & 5.93 (4.24 to 7.63$)$ & 3.73 (2.76 to 5.04$)$ & 2.10 (1.53 to 2.87$)$ \\
\hline & 1 year & 40.5 (32.4 to 49.7$)$ & 1.80 (1.30 to 2.30$)$ & 3.18 (2.38 to 4.24$)$ & 1.81 (1.34 to 2.45$)$ \\
\hline \multirow[t]{4}{*}{$>625$ to $2000 \mathrm{mg}$} & 7 days & 13.2 (8.6 to 19.9$)$ & 20.36 (11.21 to 29.52$)$ & 3.15 (1.96 to 5.06$)$ & $1,76(1.06$ to 2.94$)$ \\
\hline & 30 days & $31.2(24.4$ to 39.5$)$ & $13.15(9.31$ to 16.99$)$ & $4.03(2.95$ to 5.50$)$ & $2.08(1.48$ to 2.93$)$ \\
\hline & 90 days & 39.6 (32.1 to 48.1$)$ & 6.41 (4.75 to 8.07$)$ & 3.97 (3.01 to 5.23 ) & $2.03(1.51$ to 2.74$)$ \\
\hline & 1 year & 53.4 (45.4 to 61.8$)$ & 2.68 (2.08 to 3.28$)$ & 4.36 (3.43 to 5.54$)$ & $2.24(1.72$ to 2.91$)$ \\
\hline \multirow[t]{4}{*}{$>2000$ to $3500 \mathrm{mg}$} & 7 days & 16.4 (11.2 to 23.7$)$ & 25.67 (15.18 to 36.16$)$ & 3.98 (2.57 to 6.16$)$ & 2.74 (1.62 to 4.64$)$ \\
\hline & 30 days & 30.0 (23.2 to 38.4$)$ & 12.46 (8.69 to 16.23$)$ & 3.87 (2.81 to 5.33 ) & 2.24 (1.52 to 3.30$)$ \\
\hline & 90 days & 38.2 (30.6 to 46.8 ) & 6.12 (4.47 to 7.76$)$ & 3.80 (2.85 to 5.05$)$ & $2.17(1.54$ to 3.06$)$ \\
\hline & 1 year & $48.9(40.9$ to 57.6$)$ & $2.37(1.80$ to 2.94$)$ & 3.92 (3.05 to 5.06$)$ & $2.18(1.61$ to 2.97$)$ \\
\hline \multirow[t]{4}{*}{$>3500 \mathrm{mg}$} & 7 days & $10.5(5.6$ to 19.1$)$ & 15.71 (5.45 to 25.97$)$ & 2.44 (1.24 to 4.76$)$ & $1.55(0.75$ to 3.24$)$ \\
\hline & 30 days & 20.9 (13.8 to 31.2$)$ & 8.30 (4.47 to 12.14$)$ & 2.59 (1.61 to 4.16$)$ & $1.31(0.78$ to 2.19$)$ \\
\hline & 90 days & 26.8 (18.7 to 37.6$)$ & 3.80 (2.25 to 5.35$)$ & 2.50 (1.64 to 3.80$)$ & $1.21(0.77$ to 1.90$)$ \\
\hline & 1 year & 46.2 (36.1 to 57.7$)$ & 1.91 (1.30 to 2.52$)$ & 3.33 (2.40 to 4.63 ) & 1.59 (1.11 to 2.29$)$ \\
\hline
\end{tabular}

${ }^{*}$ Cumulative dose defined as the 1-year cumulative dose of systemic corticosteroids among current users, calculated as prednisone dose equivalents.

†HR adjusted for age, sex, use of cardiovascular medication, hypertension, COPD, liver disease or chronic pancreatitis, alcoholism-related diseases other than those affecting the liver or pancreas, inflammatory bowel disease, rheumatoid arthritis, connective tissue disease, malignancies and modified Charlson Comorbidity Index score.

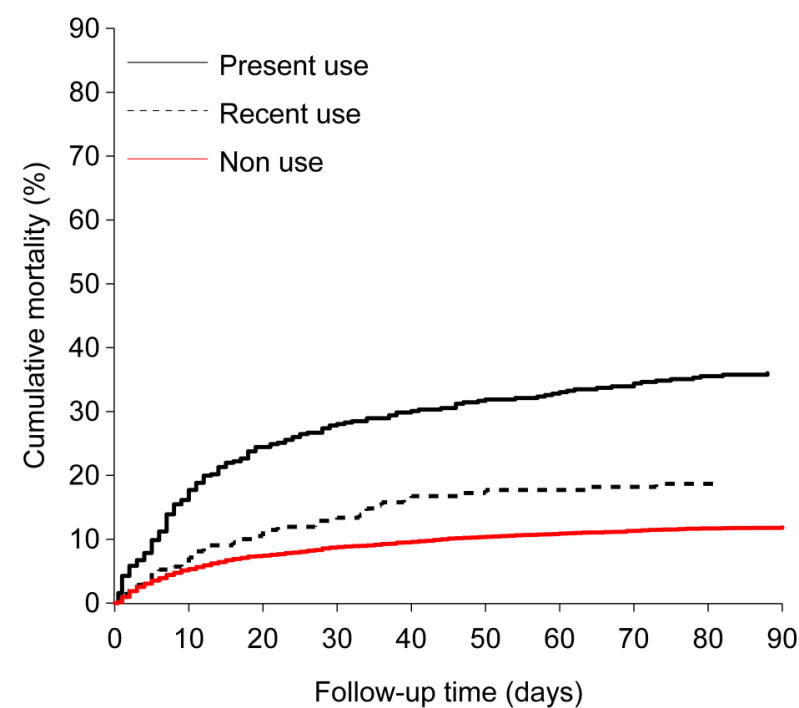

Number at risk:

$\begin{array}{lllllllll}\text { Present use } 446 & 367 & 336 & 319 & 308 & 300 & 295 & 287 & 281\end{array}$

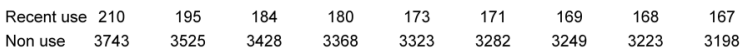

Figure 2 Cumulative mortality in patients with systemic use of corticosteroids only.

results also apply to patients using steroids with high first pass metabolism needs further study. Finally, perforated diverticular disease may be misclassified, ${ }^{6}{ }^{17}$ as the sensitivity of relevant ICD codes is not $100 \%$ accurate. Since misclassification is probably more likely in corticosteroid users (due to blinding of symptoms and severity of the condition), mortality risk is potentially overestimated if less severe cases in corticosteroid users go undetected. ${ }^{25}$ However, in analyses stratified by type of surgery, which most likely harmonises the diagnostic category, a similar increased risk was found.

The central causal question is whether increased mortality risk in corticosteroid users is actually caused by corticosteroid use prior to diagnosis. Clinical arguments underlying the rationale for a causal association are masked disease severity, ${ }^{17}$ impaired wound healing and increased infection risk, ${ }^{18}$ increased risk of venous thromboembolism ${ }^{20}$ and unrecognised adrenal insufficiency. ${ }^{29}$ The risk was doubled for corticosteroid users in our fully adjusted statistical model, but residual confounding (no perfectly valid data on actual disease severity status) might still be an issue. For instance, high mortality among patients using corticosteroids may be explained partially by the underlying diseases for which corticosteroids were prescribed. However, our subgroup analyses showed no clear differences when high-risk subgroups were excluded. Regardless of the causal question, our study indicated that corticosteroid use was an important prognostic factor for mortality.

Two explanations are possible for the lack of an association observed between mortality risk and dose. First, the risk may be associated with corticosteroid use per se, 
Table 4 Mortality among current corticosteroid users: subgroup and sensitivity analyses compared with non-use

\begin{tabular}{|c|c|c|c|c|c|}
\hline Restrictions & Period & $\begin{array}{l}\text { Absolute risk } \\
(95 \% \mathrm{Cl})\end{array}$ & $\begin{array}{l}\text { Rate per } 1000 \text { PYRs } \\
(95 \% \mathrm{Cl})\end{array}$ & $\begin{array}{l}\text { Crude HR } \\
\text { (95\% Cl) }\end{array}$ & $\begin{array}{l}\text { Adjusted HR* } \\
(95 \% \mathrm{Cl})\end{array}$ \\
\hline \multirow[t]{4}{*}{ Non-use } & 7 days & 4.4 (3.8 to 5.1$)$ & 6.46 (5.47 to 7.44$)$ & & \\
\hline & 30 days & 8.8 (7.9 to 9.7$)$ & 3.12 (2.78 to 3.45$)$ & & \\
\hline & 90 days & 11.9 (10.9 to 12.9$)$ & 1.46 (1.33 to 1.60$)$ & & \\
\hline & 1 year & $15.6(14.4$ to 16.8$)$ & $0.51(0.47$ to 0.55$)$ & & \\
\hline \multirow[t]{4}{*}{ Inhaled only } & 7 days & 6.2 (2.6 to 14.2$)$ & $9.16(1.13$ to 17.18$)$ & 1.42 (0.58 to 3.45$)$ & 1.55 (0.60 to 3.97$)$ \\
\hline & 30 days & $17.3(10.6$ to 27.4$)$ & 6.46 (3.08 to 9.84$)$ & 2.04 (1.20 to 3.49$)$ & 1.85 (1.04 to 3.27$)$ \\
\hline & 90 days & 21.0 (13.6 to 31.6$)$ & 2.83 (1.48 to 4.17$)$ & 1.87 (1.15 to 3.04$)$ & 1.72 (1.03 to 2.89$)$ \\
\hline & 1 year & 22.3 (14.7 to 33.0$)$ & 0.79 (0.43 to 1.16$)$ & 1.54 (0.96 to 2.46$)$ & 1.44 (0.88 to 2.37$)$ \\
\hline \multirow[t]{4}{*}{ Systemic use only } & 7 days & $13.9(11.0$ to 17.5$)$ & 21.30 (16.00 to 26.60$)$ & 3.30 (2.47 to 4.42 ) & 2.02 (1.44 to 2.82$)$ \\
\hline & 30 days & 28.0 (24.1 to 32.5$)$ & $11.53(9.51$ to 13.55$)$ & 3.56 (2.90 to 4.38 ) & 1.96 (1.55 to 2.48$)$ \\
\hline & 90 days & 36.0 (31.7 to 40.7$)$ & $5.60(4.73$ to 6.47$)$ & 3.52 (2.94 to 4.22 ) & $1.92(1.56$ to 2.36$)$ \\
\hline & 1 year & 48.0 (43.4 to 52.8$)$ & 2.23 (1.93 to 2.53$)$ & 3.77 (3.22 to 4.42 ) & 2.04 (1.70 to 2.45$)$ \\
\hline \multirow{4}{*}{$\begin{array}{l}\text { Systemic use, regardless of } \\
\text { other uses }\end{array}$} & 7 days & 14.2 (11.4 to 17.6$)$ & 21.81 (16.70 to 26.92$)$ & 3.38 (2.56 to 4.47 ) & 2.10 (1.52 to 2.90$)$ \\
\hline & 30 days & 27.9 (24.2 to 32.1$)$ & $11.53(9.60$ to 13.45$)$ & 3.56 (2.92 to 4.35 ) & 1.96 (1.56 to 2.47$)$ \\
\hline & 90 days & 36.6 (32.5 to 41.0$)$ & 5.71 (4.87 to 6.54$)$ & 3.59 (3.02 to 4.27 ) & 1.97 (1.62 to 2.41$)$ \\
\hline & 1 year & 47.6 (43.2 to 52.1$)$ & 2.22 (1.93 to 2.50$)$ & 3.75 (3.22 to 4.38 ) & 2.05 (1.72 to 2.45$)$ \\
\hline \multirow{4}{*}{$\begin{array}{l}\text { Excluding patients with } \\
\text { malignancies }\end{array}$} & 7 days & $14.3(11.1$ to 18.4$)$ & 21.94 (15.92 to 27.97$)$ & 4.03 (2.91 to 5.59 ) & 2.22 (1.50 to 3.28$)$ \\
\hline & 30 days & 26.3 (22.1 to 31.2$)$ & 10.80 (8.62 to 12.99$)$ & 4.04 (3.18 to 5.13 ) & 2.00 (1.50 to 2.67$)$ \\
\hline & 90 days & 32.9 (28.3 to 38.0$)$ & $5.00(4.10$ to 5.91$)$ & 3.87 (3.13 to 4.78 ) & 1.93 (1.50 to 2.48$)$ \\
\hline & 1 year & 42.3 (37.3 to 47.7$)$ & 1.85 (1.55 to 2.15$)$ & 3.93 (3.26 to 4.74$)$ & 2.03 (1.62 to 2.55$)$ \\
\hline Excluding patients with & 7 days & 14.3 (11.4 to 17.8$)$ & 21.91 (16.63 to 27.20$)$ & 3.35 (2.52 to 4.46$)$ & 2.03 (1.46 to 2.83$)$ \\
\hline \multirow{3}{*}{ inflammatory bowel disease } & 30 days & 28.1 (24.2 to 32.4$)$ & $11.58(9.59$ to 13.57$)$ & 3.54 (2.89 to 4.34$)$ & 1.89 (1.49 to 2.40$)$ \\
\hline & 90 days & 36.6 (32.4 to 41.2$)$ & 5.72 (4.86 to 6.59$)$ & 3.55 (2.97 to 4.24$)$ & 1.87 (1.52 to 2.29$)$ \\
\hline & 1 year & 48.1 (43.6 to 52.8$)$ & 2.25 (1.95 to 2.54$)$ & 3.76 (3.21 to 4.39 ) & 1.96 (1.64 to 2.36$)$ \\
\hline Excluding patients with a & 7 days & 15.7 (12.4 to 19.7$)$ & 24.47 (18.28 to 30.66$)$ & 3.43 (2.53 to 4.65$)$ & 2.06 (1.45 to 2.93$)$ \\
\hline previous code for diverticular & 30 days & 29.8 (25.5 to 34.6$)$ & $12.57(10.26$ to 14.88$)$ & 3.66 (2.94 to 4.56$)$ & 2.03 (1.58 to 2.63$)$ \\
\hline \multirow[t]{2}{*}{ disease } & 90 days & 38.5 (33.8 to 43.6$)$ & $6.15(5.16$ to 7.15$)$ & 3.67 (3.03 to 4.45$)$ & 2.01 (1.61 to 2.51$)$ \\
\hline & 1 year & 49.3 (44.4 to 54.5$)$ & 2.35 (2.01 to 2.68$)$ & 3.80 (3.20 to 4.51 ) & 2.07 (1.70 to 2.53$)$ \\
\hline Excluding patients with & 7 days & 15.3 (11.8 to 19.6$)$ & $23.73(17.22$ to 30.25$)$ & 3.72 (2.71 to 5.10$)$ & 2.13 (1.51 to 3.01$)$ \\
\hline rheumatic diseases including & 30 days & 28.5 (23.9 to 33.6$)$ & $11.87(9.48$ to 14.25$)$ & 3.71 (2.95 to 4.67 ) & 1.95 (1.52 to 2.51$)$ \\
\hline mixed connective tissue & 90 days & 37.8 (32.9 to 43.3 ) & 5.98 (4.93 to 7.02 ) & 3.79 (3.10 to 4.62$)$ & 1.95 (1.57 to 2.42$)$ \\
\hline disease & 1 year & $48.4(43.1$ to 54.0$)$ & 2.31 (1.95 to 2.67$)$ & 3.91 (3.28 to 4.67 ) & 2.06 (1.70 to 2.49$)$ \\
\hline
\end{tabular}

${ }^{*} \mathrm{HR}$ adjusted for age, sex, use of cardiovascular medications, hypertension, COPD, liver disease or chronic pancreatitis, alcoholism-related diseases other than those affecting the liver or pancreas, inflammatory bowel disease, rheumatoid arthritis, connective tissue disease, malignancies and modified Charlson Comorbidity Index score.

COPD, chronic obstructive pulmonary disease; PYR, person year.

so that the maximum increase in risk is already reached at a low (but still supraphysiological) dose. Second, our classification did not distinguish between short-term, high-dose corticosteroid use and long-term, low-dose use, because the prescription database used does not provide certainty whether a drug is prescribed in high doses for short-term use, or in lower doses for longer duration. Although clinically short-term, high-dose corticosteroid use and long-term, low-dose corticosteroid use are very heterogeneous groups of patients, in our analysis according to dose, both translate into the same 1-year cumulative dose.

In conclusion, this study demonstrated that corticosteroid use was associated with increased mortality risk after diagnosis of perforated diverticular disease. Clinically, use of systemic corticosteroids should be regarded as an important risk marker for mortality among patients with this disease.
Contributors All authors contributed to the development of the study protocol and read and approved the final manuscript. EH-P extracted the data from the National Health Service Prescription Database and the Danish National Patient Registry, and performed the statistical analyses. LHAB first analysed the rough data from the statistical analyses and summarised their implications in this article. AMP related the implications to the endocrinology practice, whereas RE did the same for the gastroenterology practice. OMD paid attention to the epidemiological correctness of the implications that were made. HTS managed the entire research process and checked the final version of the article for completeness.

\section{Competing interests None declared}

Provenance and peer review Not commissioned; externally peer reviewed.

Data sharing statement No additional data are available.

Open Access This is an Open Access article distributed in accordance with the Creative Commons Attribution Non Commercial (CC BY-NC 4.0) license, which permits others to distribute, remix, adapt, build upon this work noncommercially, and license their derivative works on different terms, provided the original work is properly cited and the use is non-commercial. See: http:// creativecommons.org/licenses/by-nc/4.0/ 


\section{REFERENCES}

1. Tanase I, Paun S, Stoica B, et al. Epidemiology of diverticular disease-systematic review of the literature. Chirurgia (Bucur) 2015;110:9-14

2. Warner E, Crighton EJ, Moineddin R, et al. Fourteen-year study of hospital admissions for diverticular disease in Ontario. Can J Gastroenterol 2007;21:97-9.

3. Stollman N, Raskin JB. Diverticular disease of the colon. Lancet 2004;363:631-9.

4. Morris CR, Harvey IM, Stebbings WS, et al. Incidence of perforated diverticulitis and risk factors for death in a UK population. $\mathrm{Br} J$ Surg 2008;95:876-81.

5. Hart AR, Kennedy HJ, Stebbings WS, et al. How frequently do large bowel diverticula perforate? An incidence and cross-sectional study. Eur J Gastroenterol Hepatol 2000;12:661-5.

6. Moore FA, Catena F, Moore EE, et al. Position paper: management of perforated sigmoid diverticulitis. World J Emerg Surg 2013;8:55.

7. Nagorney DM, Adson MA, Pemberton JH. Sigmoid diverticulitis with perforation and generalized peritonitis. Dis Colon Rectum 1985;28:71-5

8. Finlay IG, Carter DC. A comparison of emergency resection and staged management in perforated diverticular disease. Dis Colon Rectum 1987;30:929-33

9. van Staa TP, Leufkens HG, Abenhaim L, et al. Use of oral corticosteroids in the United Kingdom. QJM 2000;93:105-11.

10. Rodger RS, Watson MJ, Sellars L, et al. Hypothalamic-pituitary-adrenocortical suppression and recovery in renal transplant patients returning to maintenance dialysis. QJM 1986;61:1039-46.

11. Spiegel RJ, Vigersky RA, Oliff Al, et al. Adrenal suppression after short-term corticosteroid therapy. Lancet 1979;1:630-3.

12. Morris CR, Harvey IM, Stebbings WS, et al. Anti-inflammatory drugs analgesics and the risk of perforated colonic diverticular disease. Br J Surg 2003;90:1267-72.

13. Piekarek K Israelsson LA. Perforated colonic diverticular disease: the importance of NSAIDs, opioids, corticosteroids, and calcium channel blockers. Int J Colorectal Dis 2008;23:1193-7.

14. Humes DJ, Fleming KM, Spiller RC, et al. Concurrent drug use and the risk of perforated colonic diverticular disease: a population-based case-control study. Gut 2011;60:219-24.

15. Aldoori WH, Giovannucci EL, Rimm EB, et al. Use of acetaminophen and nonsteroidal anti-inflammatory drugs: a prospective study and the risk of symptomatic diverticular disease in men. Arch Fam Med 1998;7:255-60.
16. Kvasnovsky CL, Papagrigoriadis S, Bjarnason I. Increased diverticular complications with nonsteriodal anti-inflammatory drugs and other medications: a systematic review and meta-analysis. Colorectal Dis 2014;16:0189-96.

17. Symmonds RE Jr. Surgical management of complicated diverticulitis. Clin Geriatr Med 1985;1:471-83.

18. Guo S, Dipietro LA. Factors affecting wound healing. J Dent Res 2010;89:219-29.

19. Eriksen TF, Lassen CB, Gögenur I. Treatment with corticosteroids and the risk of anastomotic leakage following lower gastrointestinal surgery: a literature survey. Colorectal Dis 2014;16: O154-60.

20. Johannesdottir SA, Horvath-Puho E, Dekkers OM, et al. Use of glucocorticoids and risk of venous thromboembolism: a nationwide population-based case-control study. JAMA Intern Med 2013;173:743-52.

21. de Herder WW, van der Lely AJ. Addisonian crisis and relative adrenal failure. Rev Endocr Metab Disord 2003;4:143-7.

22. Johannesdottir SA, Horvath-Puho E, Ehrenstein V, et al. Existing data sources for clinical epidemiology: the Danish National Database of Reimbursed Prescriptions. Clin Epidemiol 2012;4:303-13.

23. Lynge E, Sandegaard JL, Rebolj M. The Danish National Patient Register. Scand J Public Health 2011;39(7 Suppl):30-3.

24. Schmidt M, Pedersen L, Sørensen HT. The Danish Civil Registration System as a tool in epidemiology. Eur J Epidemiol 2014;29:541-9.

25. Erichsen R, Strate L, Sørensen HT, et al. Positive predictive values of the International Classification of Disease, 10th edition diagnoses codes for diverticular disease in the Danish National Registry of Patients. Clin Exp Gastroenterol 2010;3:139-42.

26. Barksdale AN, Hackman JL, Gaddis M, et al. Diagnosis and disposition are changed when board-certified emergency physicians use CT for non-traumatic abdominal pain. Am J Emerg Med 2015;33:1646-50.

27. Christensen S, Riis A, Nørgaard M, et al. Perforated peptic ulcer: use of pre-admission oral glucocorticoids and 30-day mortality. Aliment Pharmacol Ther 2006;23:45-52.

28. Iudici M, Russo B, Mitidieri M, et al. Glucocorticoids in systemic sclerosis: patients' beliefs and treatment adherence. Scand $J$ Rheumatol 2015;44:229-37.

29. Broersen LH, Pereira AM, Jørgensen JO, et al. Adrenal insufficiency in corticosteroids use: systematic review and meta-analysis. J Clin Endocrinol Metab 2015;100:2171-80. 